\title{
Current Exchange Rate Challenges And Nigeria's Balance of Payment
}

\author{
Ugwu Okereke J. (Ph.D) \\ Department Of Accountancy, Banking And Financeebonyi State University, Abakaliki
}

\begin{abstract}
This study examines the impact of Exchange rate fluctuations on balance of payment in Nigeria for the sample period 1986 to 2015. The estimation procedure adopted for the study was multiple regression method based on Ordinary Least Squares technique. However, in order to avoid the incidence of spurious estimates, evidence from the ADF test conducted revealed that the variables are integrated of order two, $1(1)$. The Johansen test conducted showed evidence of long run equilibrium relationship between Exchange rate fluctuations and balance of payment. The findings from the study showed that there is a statistical significance between Exchange rate fluctuations on balance of payment in Nigeria as shown by the joint variation of the $t$ and fest and their respective P-values. The study therefore recommends that government expenditure should be increased on capital projects, the Naira should be devalued with respect to other currencies of the world especially the U.S. dollars and effective diversification of the economy encouraged with agricultural exports stimulated.
\end{abstract}

Keywords: Domestic debt, economic Growth, Nigeria, debt outstanding

\section{Introduction}

Exchange rate refers to the price of one currency (the domestic currency) in terms of another (the foreign currency) (Oladipupo and Ogbeneovo, 2011). Or it can be simply defined as the price of one country's currency expressed in terms of some other currency. It determines the relative prices of domestic and foreign goods, as well as the strength of external sector participation in the international trade. Exchange rate plays a vital role in international economic transactions because no nation can remain in self sufficiency due to varying factor endowment. Exchange rate has a constant effect on other economic variables such as interest rate, inflation rate, unemployment, money supply etc, these facts underscore the importance of exchange rate to the economic well being of every country that opens its doors to international trade in goods and services. The importance of exchange rate is derived from the fact that it connects the price system of two different countries making it possible for international trade to make direct comparison of traded goods. In other words, it links domestic price with international prices. Through it effects on th volume on imports and exports, exchange rate exerts a powerful influence on a country's balance of payment (BOP) position. Consequently, nations in a pursuit of the macroeconomic goals of healthy external balances as reflected in their balance of payment (BOP) position, find it imperative to enunciate an exchange rate policy.

Exchange rate is a key determinant of the balance of payment (BOP) position of any country. If it is judiciously utilized, it can serve as normal anchor for price stability. Changes in exchange rate have direct effect on demand and supply of goods, investment, employment, as well as distribution of income and wealth (Oladipupo andOgheneovo 2011).

When Nigeria started recording huge balance of payments deficit and very low level of foreign reserve in the 1980s, it was felt that a depreciation of the naira would relieve pressures on the balance of payments. Consequently, the naira was devalued. The irony of this policy instrument is that over foreign trade structure did not satisfy the condition for a successful balance of payment policy. This country's foreign structure is characterized by export of crude petroleum and agricultural produce whose prices are predetermined in the world market and low import and export price elasticity's of demand.

The balance of payments (BOP) is the method countries use to monitor all international monetary transactions at a specific period of time. All trade conducted by both the private and bublic sectors are accounted for in the BOP in order to determine how such money is going in and out of a country. Paul (1996) defines balance of payments as an accounting record of all monetary transactions between a country and the rest of the world. These transactions include payments for the country's exports an imports of goods, services and financial capital, as well as financial transfer. It summarizes the international transaction for a specfic period, usually one year and it is prepared in single currency for the country concerned. Nzotta (2004) defines foreign exchange as the value of foreign nation's currency in terms of the home nation currency. In finance, the exchange rate (as also known as the foreign exchange rate or forex rate) between two currencies specify how much one currency is worth in terms of the other. 
Nigeria is currently facing serious problems regarding its foreign exchange rating (which is very low in comparison to other countries) and it's Balance of payment which is clearly in disequilibrium and in a deficit. As a result of this the government is retrogressing and the citizens clearly suffering. It is in a bid to discover why this is so and how this can be solved that this study is necessitated.

In Nigeria, exchange rate has become a subject of immense interest, in recent times to economists, policy makers, traders and ordinary citizens. Almost all the players in the economy including the government and corporate bodies see exchange rate as the causes of decline in economic activities in a country due to its instability. Exchange rate and balance of payment are the key factors of a nation's life. They are also factors to look into when comparing a country's relationship with other nations. These factors directly or indirectly affect a host of other factors which are of severe importance in any nation. These two factors can be said to have crippled the Nigeria economy and made life uncomfortable and unbearable for it citizens.

Currently, the nation's exchange rate has fallen so low due to unfavourable nature of the competing power of the nation's currency with foreign currencies of the world. Our economy has been trying to resolve the problem of external and internal balance, which has manifested in disequilibrium in our balance of payment and causing us a balance of payment deficit.

It is against this background that the study is hinged on the impact of exchange rate fluctuation on balance of payments in Nigeria. The broad objective of the study is to determine the impact of exchange rate fluctuations on balance of payment in Nigeria. Specifically, the study is to; determine the impact of interest rate on balance of payment in Nigeria and examine the impact of inflation rate on balance of payment in Nigeia.

This study focused on the relationship between exchange rate and balance of payment position for the period 1986-2015. This duration scope is chosen because it is believed to have covered the period of flexible exchange rate period and is large enough for statistical analysis. The variable scope for this research is limited to the illusion of exchange rate figures, interest rate and time series data representing the level of balance of payment for the year stated above, in order to determine the impact of exchange rate on balance of payment in Nigeria, as its fluctuations steadily affects the balance of payments position on Nigeria economy.

\section{Review of Related Literature}

Olu (2010), on his study of price and exchange rate stability in Nigeria on determining the relationship between changes in exchange rate and changes in prices in Nigeria, he discovered that changes in exchange rate causes inflation in Nigeria using grange causality test. He further discovered that there seems to be a chicken and egg relationship between minimum rediscount rates (MRR).

Kamin and Klau (1998), using an error correlation technique estimated a regression equation linking the output to the real exchange rate for a group of twenty seven countries, reverse causality appeared to alternate the measured contractionary effects of deduction in the short-term although, the effect persisted even after the introduction of controls. Apart from the findings from simulation and regression analysis, result from models, mainly on the effects of the exchange rate on the output parse, are equally in formative.

Agenor (1995), using a sample of twenty-three developing countries, regressed output growth on contemporaneous and lagged level of the real exchange rate and no deviations of actual changes from expected ones in the real exchange rate, government spending and foreign income. The results showed that surprises in real exchange rate depreciation actually boosted output growth, but that depreciation of the level of the real exchange rate exerted a contractionary effect.

Morley (1992), in his study "effects of real exchange rate on output" analyzed the effect of real exchange rates on output for twenty-eight developing countries that have devalued their currencies using a regression analysis. After introduction of controls for factor that could simultaneously introduced devaluation and reduced output including fiscal balance, money supply and import growth, discovered that depreciation of the level of the real exchange rate reduced the output.

Odusola and Akinlo (2001), in their studies examined the linkage among exchange rate, inflation and output in Nigeria. A structural VAR model was employed which captured the interactions between exchange rate and output. Evidence from the contemporaneous model showed a contractionary impact of the parallel exchange rate, price and lending rate were found to be important sources of obstruction in the official exchange rate. In addition output and parallel exchange rate were significant determinants of inflation dynamics in Nigeria. The authors concluded by suggesting more concerted efforts by the central bank towards taming the parallel exchange rate behaviour and formulating monetary policies that enhance income growth. Largely the findings were informative.

Aliyu (2009), in his study "exchange rate" also examined exchange rate pass-through in Nigeria for the period 1986 to 2009. Quarterly series was employed and vector error correlation model estimation was used in the estimation process. The author found that exchange rate pass-through is always considerably higher in 
developing countries than developed countries. He concluded that in the long-run, pass-through would likely increase and monetary policy should be designed to accommodate the effect.

Kiguel and Ghei (1993), in their studies show that exchange rate affects balance of payments, using the ratio of non-gold reserve to import the impact of devaluation on the balance of payments. Their results show that the reserve position of the devaluating country improves the balance of payments, since an improvement on the reserve position constitutes an improvement on balance of payments position.

Oguro (2008), in his study opines that sensitivity of export trade to exchange rate changes is dependent on certain conditions. Using a six-industry panel data to investigate industry specific sensitivity of exports to exchange rates for 38 trading pairs including China, USA, and Japan, he concluded that high inter-industry trade reduces the exports sensitivity to exchange rates due to lower electricity of substitution among differentiated productions but where inter-industry trade does not exit, exchange rate changes affects exports trade. The existence of these conditions according to Cui and Syed (2007), does not eliminate the dependence of export trade on the exchange rate volatility, insisting that China's trade growth with the USA is hinged favourable exchange rate of china's Yuan to the U.S dollar. Available data indicate that the over-valuation of the naira exchange rate which characterized the erstwhile rigid exchange rate regime has been largely eliminated. The over-valuation of the naira exchange rate measured against PP equilibrium was about $200 \%$ in the pre SAP period and was eliminated by 1987 (Nwachukwu, 1993). Also, the parallel premium which was over 300\% in 1985 has been drastically reduced. However, in recent months, the naira exchange rate has exchange rate as a function of many variables notable, the relative inflation and interest rates between Nigeria and her trading partners as well as the incidence of speculation, among others. Consequently, stability of the variables themselves should be as stable as possible. Thus, the viability and stability of the exchange rate in the future requires a consideration the future stability of those variables that influence the rate.

However, to ensure that the factor that determines the rate achieve their desired objectives, it is necessary that the factors themselves should move freely to reflect changes in economic fundamentals. It is therefore necessary to assume that economic policy will continue to be formulated within the framework of the liberalized and deregulated economic environment, where economic agents are free to respon to free market originals it should however, be noted that it might be expedient as a matter of deliberate policy to allow the exchange rate to diverge from equilibrium in this regard, the exchange rate of a currency could remain undervalued if policy is to encourage exports, given the right conditions. Some newly industrialized countries of Asia pursued this line of policy to encourage their manufacturing sectors to produce exports.

The assertion here is that, since the naira exchange rate is still unstable, there is need to intensify actions to push it towards equilibrium. The future stability of the naira exchange rate will depend on efforts to reduce the pressure on the general level of prices, reduce the huge fiscal deficit, harmonize fiscal and monetary policy and reduce the excess demand for foreign exchange.

\section{Methodology}

The study is an empirical study. For this study, ex post facto research design was adopted. This is because the data used in this study already exist and cannot be manipulated. Ex-post facto research is systematic empirical inquiry in which the scientist does not have direct control of independent variables because their manifestations have already occurred or because they are inherently not manipulated. This study also makes use of quantitative research design in analyzing the data. The research used only the secondary source of data due to the nature of information. The data were generated from the publications by the central bank of Nigeria (CBN), the CBN statistical bulletin of various years, national bureau of statistics, CBN annual report and statement of accounts, journal and text books, Federal government of Nigeria (FGN) national account, Federal office of statistics (FOS) annual abstract of statistics and digest of statistics.

In the study, the research adopted multiple regression analysis in order to test the three objectives and hypotheses stated in chapter one above.

The models are specified as follows: $\mathrm{BOP}=\mathrm{F}(\mathrm{EXR}, \mathrm{INT}, \mathrm{INFR}$,$) \quad (1) and \mathrm{BOP}_{\mathrm{t}}=\alpha+\mathrm{b}_{1} \mathrm{EXR}_{\mathrm{t}}+$ $\mathrm{B}_{2} \mathrm{INTR}_{\mathrm{t}}+\mathrm{B}_{3} \mathrm{INFR}_{\mathrm{t}}+\mathrm{e}_{\mathrm{t}}(2)$

As we have earlier stated, the main method of data analysis in this work is multiple regression. The method is chosen on account of its ability to predict long term financial dynamic with its popularity in previous empirical works. The specified multiple regression models will be estimated using the Ordinary Least Squares (OLS) technique. The following econometric and statistical diagnostic tests will be performed in order to ascertain the validity of the regression results: Unit Root Tes, Augmented Dickey fuller (ADF) was employed for this study.

The general form of Augmented Dickey fuller (ADF) test is estimated by the following regression.

$$
\begin{aligned}
& \Delta \mathrm{y}_{\mathrm{t}}=\alpha_{0}+\alpha_{1} \mathrm{y}_{\mathrm{t}-1}+\sum \alpha \Delta \mathrm{y}_{\mathrm{i}}+\varepsilon_{\mathrm{t}} \\
& \Delta \mathrm{y}_{\mathrm{t}}=\alpha_{0}+\alpha_{1} \mathrm{y}_{\mathrm{t}-1}+\sum \alpha \Delta \mathrm{y}_{\mathrm{i}}+\delta_{\mathrm{t}}+\varepsilon_{\mathrm{t}}
\end{aligned}
$$


Additionally, according to Engle-Granger (1987) when variables were found to be 1(1), stationarity of residual (obtained from a static regression) implies co-integration, meaning that a long run equilibrium condition exists between the dependent and the independent variables. The residual series is included in the regression as an error correcting mechanism. Long run regression results are obtained by traditional Ordinary Least Squares (OLS) techique. Therefore to oberve the nature of co-integration we employ the Johansen model. The test is calculated as follows:

$$
\lambda \operatorname{trace}(r)=-T \sum \operatorname{In}\left(1-\lambda_{t}\right)
$$

Where

$\mathrm{T}$ is the number of usable observations, and the $\lambda_{1}, \mathrm{~s}$ are the estimate eigen value from the matrix. The second statistical test is the maximum eigen value test $\left(\lambda_{\max }\right)$ that is calculated according to the following formula.

$$
\lambda_{\max }(\mathrm{r}, \mathrm{r}+1)=\mathrm{T} \operatorname{In}(1-\lambda \mathrm{r}+1)
$$

The test concerns a test of the null hypothesis that there is (r) of co-integrating vectors against the alternative that $r+1$ co-integrating vector.

Under the statistical test, we will test for the goodness of fit, the individual significance of each regression using the t-test and finally the significance of the regression models using the f-test.

\section{Result Presentation}

The attempt to study the effect of Exchange rate fluctuations on balance of payment in Nigeria led the researcher to subject the data collected to Unit root test, Cointegration test and the Ordinary Least Square (OLS). The results and their discussions are presented here under.

\section{Unit root test}

The use of time series data for estimating the parameters of economic relationship among variables is predicated upon some assumptions, one of which is that such a data series is stationary. In this context, testing for stationarity or otherwise of the employed data sets becomes of essence in this analysis. The Augmented Dickey fuller (ADF) was employed to test for the existence of unit roots in the data using trend and intercept. The test results are presented in the table below:

Table 1: ADF Unite Root Result Test

\begin{tabular}{|l|l|l|l|l|l|}
\hline Series & ADF @ Level & $\begin{array}{l}\text { ADF @ 1 } \\
\text { Difference }\end{array}$ & $\begin{array}{l}\mathbf{5 \%} \text { critical } \\
\text { value }\end{array}$ & $\begin{array}{l}\text { Order of co- } \\
\text { integration }\end{array}$ & Remark \\
\hline BOP & -2.153319 & -5.682394 & -3.612199 & $1(1)$ & Stationary \\
\hline EXR & -1.974876 & -5.742048 & -3.612199 & $1(1)$ & Stationary \\
\hline INTR & -3.437561 & -6.527656 & -3.612199 & $1(1)$ & Stationary \\
\hline INFR & -2.481111 & -10.41214 & 3.658746 & $1(1)$ & Stationary \\
\hline
\end{tabular}

Source: Researcher's compilation from E-view (version 7.0)

Table 1 above shows the summary of unit root test results. The result shows that noe of the variables; BOP, EXR, INTR and INFR was statistionary at levels using Augmented Dickery Fuller test. This is because their critical values were greater than ADF test statistics in absolute value at $5 \%$ level of significance. However, all the variables considered became statistionary after first difference since their ADF test statistics were greater than their critical values in absolute value. The results show that the series are integrated of the same order; I (1) with the application of both ADF test. Therefore, the variables are fit to be used for the analytical purpose for which they were gathered.

\section{Conintegration Test Result}

Johansen co-integration test determine whether there exist long-term relatinship in the variables or not. The test envisages that there can be just one relatinship between variables in long term. In most cases, if two variables that are I (1) are linearly combined, the combination will also be I (1). More generally, if variables with differing orders of integration are combined, then the combination will have an order of integration equal to the largest. The model with lag 1 was chosen with the linear deterministic test assumption and the result is presented below:

Table 2. Cointegration Result Test Unrestricted Cointegration Rank Test (Trace)

\begin{tabular}{|lll|l|l|l|l|}
\hline Hypothesized & No. of & Eigen value & Trace Statistic & $\mathbf{0 . 0 5}$ Critical value & Prob.*** \\
\hline
\end{tabular}




\begin{tabular}{|l|l|l|l|l|}
\hline CE(s) & & & & \\
\hline None* & $\mathbf{0 . 8 1 2 5 8 4}$ & $\mathbf{8 2 . 0 3 4 4 0}$ & $\mathbf{4 7 . 8 5 6 1 3}$ & $\mathbf{0 . 0 0 0 0}$ \\
\hline At most 1* & $\mathbf{0 . 7 1 6 5 9 8}$ & $\mathbf{4 1 . 8 4 8 2 0}$ & $\mathbf{2 9 . 7 9 7 0 7}$ & $\mathbf{0 . 0 0 1 3}$ \\
\hline At most 2* & $\mathbf{0 . 3 8 0 7 9 5}$ & $\mathbf{1 1 . 5 8 6 8 9}$ & $\mathbf{1 5 . 4 9 4 7 1}$ & $\mathbf{0 . 1 7 7 8}$ \\
\hline At most 3* & $\mathbf{0 . 0 0 3 4 6 2}$ & $\mathbf{0 . 0 8 3 2 3 3}$ & $\mathbf{3 . 8 4 1 4 6 6}$ & $\mathbf{0 . 7 7 3 0}$ \\
\hline
\end{tabular}

Trace test indicates 4 cointegrating eqn(s) at the 0.05 level

Sources: Researcher's compilation from E-view (version 7.0)

Under the Johansen Co-integration test, co-integration is said to exist if the values of computed Eigen values are significantly different from zero or if the trace statistics is greater than the critical value at 5 percent level of significance. The results of the co-integration in table 4 above indicated two co-integrated equation. This is because trace statistics is greater than the critical value at 5 percent level of significance in only of the hypothesis equations. Similarly, the computed Eigen value is significantly different from zero in one of the hypothesized equations. Hence, two of the hypothesized equations satisfies this condition and therefore the null hypothesis of no co-integration among the variables is rejected in at least one equation. There is therefore a long run relationship between the variables used for the analysis in Nigeria within the period under study 1986-2015.

In this study, mathematical relationship between the variables are established. Available data on Balance of Payment (BOP), Interest rate (INTR), Exchange Rate (EXR) and Inflation rate (INFL) were collected and used for the purpose of this analysis. Simple regression model is formed to capture the assumed relationship between these variables.

Table 3: Research Result Test Included observations: 30

\begin{tabular}{|l|l|l|l|l|}
\hline Variable & Coefficient & Std. Error & t-Statistic & Prob. \\
\hline C & 14.69853 & 4.262407 & 3.448411 & 0.0023 \\
\hline EXR & 0.059374 & 0.018124 & 3.275956 & 0.0035 \\
\hline INTR & -0.052599 & 0.233315 & -0.225443 & 0.8237 \\
\hline INFR & 0.107714 & 0.061379 & 1.754898 & 0.0932 \\
\hline
\end{tabular}

R-squared

0.725078

Adjusted R-squared $\quad 0.646679$

F-statistic

5.422012

Prob(F-statistic) $\quad 0.006028$

Durbin-Watson stat $\quad 1.719130$

Sources: Researcher's compilation from E-view (version 7.0)

The value of the intercept which is 14.69853 shows that Balance of Payment in Nigeria will experience 14.69853 unit increases when all other variables are held constant. The coefficient of Interest rate (INTR) is 0.0052599. This shows that interest rate is negatively related to Balance of Payment in Nigeria, that a unit increase in (INTR) is followed by a decrease in Balance of Payment in Nigeria. The coefficient of Exchange rate (EXR) is 0.059374 . This shows that exchange rate is positively related to Balance of Payment in Nigeria, that a unit increase in (EXR) is followed by an increase in Balance of Payment in Nigeria. Furthermore, the value of Inflation rate shows a positive relationship with Balance of Payment in Nigeria with a value of 0.107714, this implies that a unit increase in Balance of Payment in Nigeria is been followed by an increase Balance of Payment in Nigeria.

The test is carried out to check for the individual significance of the variables. Statistically, the tstatistics of the variables under consideration is interpreted based on the following statement of hypothesis. However, the individual parameters are not significant.

Decision Rule: If $\mathrm{t}$-calculated > t-tabulated, we reject the null hypothesis (Ho) and accept the alternative hypothesis $\left(\mathrm{H}_{1}\right)$, and if otherwise, we select the null hypothesis $\left(\mathrm{H}_{0}\right)$ and reject the alternative hypothesis $\left(\mathrm{H}_{1}\right)$. Level of Significance $=$ at $5 \%$, Degree of freedom: n-k, Where $\mathrm{n}$ : Sample size, K: number of parameter

Table 4: T test statistics table

\begin{tabular}{|l|l|l|}
\hline Variables (t-value) & P-value & Remark \\
\hline INTR (-0.225) & $0.0823>0.05$ & Insignificant \\
\hline EXR (3.27) & $0.0035>0.05$ & Insignificant \\
\hline INF (1.75) & $0.09>0.05$ & Insignificant \\
\hline
\end{tabular}

Source: Author's Compilation, 2016.

The $t$-statistics is used to test for individual significance of the estimated parameters ( $\beta 1, \beta 2$ and $\beta 3$ ). From the table above, we can deduce that all the variables employed are statistically significant given that their $\mathrm{T}$-value is greater than T-tabulated value. Apart from inflation rate I which has its p-value greater than 0.05 
level of significance in this case, we therefore accetp $\mathrm{H}_{1}$ and reject the null hypothesis for the individual variables in the model employed indicating significant in at least two variables employed.

(F-test)

The F-statistics is used to test for simultaneous significance of all the estimated parameters.

$H_{0}: \beta 1=\beta 2=\beta 3, H_{1}: \beta 1 \neq \beta 2 \neq \beta 3$, Level of significance $\alpha$ at $5 \%$ and Degree of freedom $k-1, n-k$

Decision Rule: If the f-calculated is greater than the f-tabulated (f-cal $>f$-tab) reject the null hypothesis $\left(\mathrm{H}_{0}\right)$ that the overall estimate is not significant and conclude that the overall estimate is statistically significant. From the result, f-calculated (5.422012) is greater than the f-tabulated (2.95), that is, f-cal > f-tab. Hence we reject the null hypothesis $\left(\mathrm{H}_{0}\right)$ that the overall estimate has a good fit which implies that our independent variables are simultaneously significant.

The $\left(\mathrm{R}^{2}\right)$ shows the amount of the variation in the dependent variables (GDP) that are explainable by the explanatory variable. The $\left(\mathrm{R}^{2}\right)$ which measures the overall goodness of fit of the entire regression shows the value of $0.7250=72.50 \%$ approximately $73 \%$. This indicates that the independent variables accounts for about $73 \%$ of the variation in the dependent variable.

The computed DW is 1.71 , at 5\% level of significance with three explanatory variables and 26 observations, the tabulated DW for $\mathrm{d} 1$ and du are 1.26 and 1.65 respectively. The value of DW is less than the lower limit. Therefore, we conclude the there is evidence of positive first order serial correlation.

The OLS result indicates that Exchange rate has a positive relationship with balance of payment though the p-value shows that the coefficient is significant. Therefore, we reject the null hypothesis and conclude that exchange rate has significant positive impact on balance of payment within the year under review.

Secondly, the OLS result indicates that Interest rate has a negative relationship with balance of payment though the p-value shows that the coefficient is insignificant. Therefore, we accept the null hypothesis and conclude that there is no significant positive impact of Interest rate on balance of payment position in Nigeria within the year under review.

\section{Hypothesis Three}

Thirdly, the OLS result indicates that Inflation rate has a positive relationship with balance of payment though the p-value shows that the coefficient is not significant. Therefore, we accept the null hypothesis and conclude that Inflation rate has no significant positive impact on balance of payment (BOP) position within the year under review.

\section{Conclusion}

The study examined the impact of exchange rate variations on Balance of Payments position in Nigeria during alternative economic regimes. From the results and findings, it was discovered that exchange rate has serious implication on balance of payments position during the deregulated than regulated period. This is shown by the higher value of the coefficient of determination of the Balance of Payments model in the deregulated period. Also, exchange rate and balance of payment, appeared with the appropriate sign and were statistically significant during the deregulated period than the regulated period, again we found that exchange rate is a determinant of balance of payments position, and its fluctuations steadily affect the balance of payments position. Therefore there is need for export diversification, since the prospects of traditional agricultural export products in the world market are not bright. We hope that the balance of payments position can be improved, if the recommendations made in this study are implemented without compromise.

Our external sector problem has to be tackled simultaneously from two angles namely: boosting supply of goods and other services to other economies and managing demand. In this regard, debt service ratio has to be looked at so that it does not become too high as to erode the stability of domestic economy. Also, frivolous imports should be cut down to free more resources for meaningfull investments. It is also important that monetary and fiscal policies have to be properly coordinated and harmonized in order to achieve macroeconomic stability. The situation where monetary policy adjusts passively to the explanatory fiscal operations of government should be avoided.

Discipline has to be maintained in the foreign exchange market and the parallel foreign exchange market considered illegal in other to achieve the objective of having a realistic exchange rate. Moreso, it is important that the exchange rate is not over valued, because this will result in unsustainable balance of payments and escalating external debt stock. In contrast, the exchange rate should find its equilibrium level to make the balance of payments position viable.

\section{References}

[1]. Agenor, P. R. (1995). Output, Devaluation and the Real Exchange Rate in Developing Countries. Weltwints Chaftlich Archiv, 127 (1), $18-41$. 
[2]. Aliyu, S. U. R. (2009). Exchange Rate Pass-through in Nigeria. Evidence from a vector Error Correlation model. Paper presented at the CSAE Conference, Oxford University, UK, 5(7) 22-35.

[3]. Central Bank of Nigeria (2014). Annual Report and statement of Account (2009, 2010, 2014 and 2015).

[4]. Central Bank of Nigeria National Bureau of Statistics, Annual Statistical Report (2014).

[5]. Central Bank of Nigeria Statistical Bulletin (2015).

[6]. Cui, T. \& Syed, A. (2007). The Shifting Structure of China's Trade and Production. IMF Working Paper, 11 (214), 1-29.

[7]. Engle, R. F, \& Granger C. W. J. (1987). Co-integration and Error Correction. Representation, Estimation and Testing Econometrica. $30(55), 1-87$.

[8]. Kamin, S. B, \& Klau, M. (1998). Some Multiple Country Evidence on the Effects of Real Exchange Rates on Output. International Finance Discussion papers, 20 (611), 456-503.

[9]. Kiguel, N. \& Ghei, M. A. (1993). Devaluation in low inflation economies. World Bank.

[10]. Kim, T. (1993). International Money and Banking. London: Knowledge publishers.

[11]. Morley, T. (1992). International Money and Banking. London: Knowledge publishers.

[12]. Nzotta, S. M. (2004). Money Banking and Finance, Theory and practice. Owerri: Hudson-Judge Nigerian Publishers.

[13]. Obaseki, P. J. (1991). Foreign Exchange Management in Nigeria. Past, present and future. CBN Economic and Financial Review, 34(4), 200-234.

[14]. Odusola, A. F. \& Akinlo, A. E. (2000). Output, Inflation and Exchange Rate in Developing Countries. An Application to Nigeria, 39 (2), June 2000. 199-222.

[15]. Oguuro, F. B. (2008). Foreign exchange mamagement and balance of payments in nigeria (Unpublished Doctoral Thesis). Rivers State University of Science \& Technology, Port Harcourt, Nigeria.

[16]. Ojo, M. O. (1990). The Management of Foreign Exchange under Nigeria SAP. CBN Economic and Financial Review, 28 (2), $70-$ 82.

[17]. Oladipupo, A. O. \& Ogbeneovo, F. O. (2011). Impact of Exchange Rate on Balance of Payment in Nigeria. An International Multidisciplinary Journal, Ethopia, 5(4), 73-88.

[18]. Olu, M. O. (2010). Monetary Policy in Nigeria in the 1980s prosperity in the 1990s UNUWIDER. Discussion Paper. 2003. 5(19), 98-115.

[19]. Paul, R. R. (1996). Money, Banking and Internatinal Trade. New Delhi: Kalyani Publishers. 